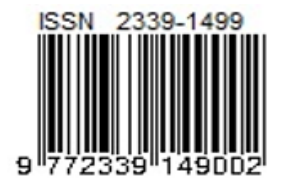

Paper ini telah direview dan dipublikasikan di Jurnal Rekayasa Sistem Industri

Volume 6 No.2 Oktober 2017

http://journal.unpar.ac.id/index.php/jrsi/index

ISSN 2339-1499 (online)

\title{
Pembuatan Masterplan Sistem Smart Green Car Indonesia 2025 Menggunakan Konsep System Engineering
}

\author{
Fran Setiawan', Syifa Fitriani ${ }^{2}$, Citrasari Andadari ${ }^{3}$ \\ 1) Fakultas Teknologi Industri, Program Studi Teknik Industri, Universitas Katolik Parahyangan \\ Jl. Ciumbuleuit 94, Bandung 40141 \\ Email: fransetiawan@unpar.ac.id \\ 2,3) Fakultas Teknik, Program Studi Teknik Industri, Universitas Gadjah Mada \\ Jl. Grafika No 2, Yogyakarta 55281 \\ Email: syifafitriani@ymail.com, citrasari.andadari@gmail.com
}

\begin{abstract}
In transportation activity, human need a transportation equipment such as car, motorcycle, plane, train, etc. As the number of urban population increase, the number of vehicle increase also, especially for country which has a big number of urban population like Indonesia. The more vehicle and private vehicle owned by urban population cause some effects. The first effect is air pollution that is caused by internal combustion engine gas emission that can give bad effect to human's health. Second, the increasing consumption of fossil fuel which is one of unrenewable natural resources that we must keep the level of consumption so that we are not run out of fuel before it can be produced again. Third is the increasing of traffic accident which are caused by human error. Therefore, it is important to make a concept about future vehicle which is not use fossil fuel, environmentally friendly and equipped with smart system to prevent accidents. This research aim is to develop a car system concept which can help to solve this problem in Indonesia in 2025 using system engineering methodology from INCOSE which begin with need identification, stakeholder identification (context diagram), concept of operations (ConOps), stakeholder requirement (core functional matrix and QFD) and system architecting. The result of this research is a smart green car system masterplan in Indonesia in 2025.
\end{abstract}

Keywords: masterplan, smart car, future, environmentally friendly, system engineering

\section{Abstrak}

Dalam melakukan aktivitas transportasi, manusia membutuhkan alat transportasi seperti mobil, sepeda motor, pesawat, kereta api, dll. Seiring bertambahnya jumlah penduduk maka jumlah kendaraan juga semakin meningkat, khususnya untuk negara dengan jumlah penduduk yang besar seperti Indonesia. Semakin banyaknya jumlah kendaraan atau kendaraan pribadi yang dimiliki menimbulkan beberapa dampak. Dampak pertama adalah polusi udara yang disebabkan oleh gas buang dari kendaraan bermotor yang dapat memberikan dampak buruk bagi kesehatan manusia. Dampak kedua adalah meningkatnya konsumsi bahan bakar minyak yang merupakan salah satu sumber daya alam yang tidak dapat diperbaharui yang harus kita batasi jumlah penggunaannya agar tidak habis sebelum dapat dihasilkan kembali. Dampak ketiga adalah meningkatnya jumlah kecelakaan lalu lintas yang disebabkan oleh kesalahan manusia. Oleh karena itu diperlukan sebuah konsep sistem kendaraan masa depan yang tidak menggunakan bahan bakar minyak, ramah lingkungan dan dilengkapi dengan sistem pintar untuk mencegah terjadinya kecelakaan. Penelitian ini akan mengembangkan konsep sebuah sistem kendaraan mobil yang dapat membantu menyelesaikan permasalahan diatas di Indonesia pada tahun 2025 menggunakan konsep system engineering dari INCOSE yang dimulai dari identifikasi kebutuhan, identifikasi stakeholder (context diagram), concept of operations (ConOps), stakeholder requirement (core functional matrix dan QFD) dan system architecting. Hasil dari penelitian ini adalah sebuah masterplan sistem smart green car di Indonesia pada tahun 2025.

Kata kunci: masterplan, mobil pintar, masa depan, ramah lingkungan, system engineering 


\section{Pendahuluan}

Transportasi merupakan salah satu aktivitas yang sangat penting dalam kehidupan manusia. Transportasi dapat membuat manusia berpindah dari satu tempat ke tempat lain, selain itu juga untuk memindahkan barang dari satu tempat ke tempat lain. Untuk melakukan aktivitas tersebut manusia membutuhkan alat transportasi (kendaraan) seperti mobil, sepeda motor, sepeda, bus, kereta, pesawat terbang, kapal dan lain-lain. Seiring bertambahnya jumlah penduduk maka meningkat pula jumlah kendaraan yang dibutuhkan, khususnya untuk negara-negara dengan jumlah penduduk yang besar seperti Indonesia yang jumlah penduduknya lebih dari 257 juta jiwa (Tribun Jateng, 2016). Berdasarkan data yang ada pada tahun 2000-2013 jumlah kendaraan di Indonesia terus mengalami peningkatan dari tahun ke tahun (Badan Pusat Statistik, 2014) seperti dapat ditunjukkan pada gambar 1 dibawah ini.

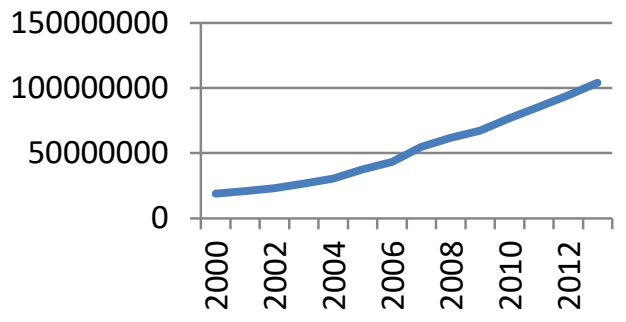

Gambar 1. Peningkatan perkembangan jumlah kendaraan bermotor (Sumber: Badan Pusat Statistik, 2014)

Dengan semakin banyaknya kendaraan pribadi yang dimiliki maka polusi udara yang disebabkan oleh gas buang dari kendaraan bermotor yang menggunakan internal combustion engine (menggunakan bahan bakar minyak) juga meningkat. Polusi udara dari gas buang kendaraan bermotor dapat memberikan dampak buruk bagi kesehatan manusia. Peningkatan jumlah kendaraan bermotor juga mengakibatkan meningkatnya jumlah kecelakaan lalu lintas yang mengakibatkan meningkatnya jumlah korban jiwa. Dari data yang ada diketahui bahwa $90 \%$ penyebab kecelakaan lalu lintas (Ditlantas Polda Metro Jaya, 2012) disebabkan oleh kesalahan manusia (human error) seperti misalnya kurangnya konsentrasi, mengantuk, terburuburu, kesalahan pengendara lain, dsb. Kecelakaan akibat kesalahan manusia ini disebabkan karena kendaraan dikemudikan oleh manusia (manual driving). Hal itu terjadi dikarenakan manusia memiliki keterbatasan baik secara fisik, mental maupun fokusnya. Selain itu peningkatan jumlah kendaraan bermotor berakibat pula pada meningkatnya konsumsi bahan bakar minyak yang merupakan salah satu sumber daya alam yang tidak dapat diperbaharui (unrenewable resources) karena membutuhkan waktu yang sangat lama untuk mendapatkannya sehingga jumlah penggunannya harus dibatasi agar dapat digunakan juga oleh generasi yang akan datang. Penggunaan bahan bakar minyak yang berlebihan dapat mengakibatkan bahan bakar minyak dapat habis sebelum dapat dihasilkan kembali.

Berdasarkan data yang diperoleh dari Kementrian Energi dan Sumber Daya Mineral (ESDM), bahan bakar minyak (BBM) masih menjadi energi paling besar yang dikonsumsi dibandingkan dengan jenis energi lainnya. Konsumsi BBM pada tahun 2011 mencapai 365 juta SBM. Data konsumsi energi di Indonesia dapat dilihat pada gambar 2 dibawah ini.

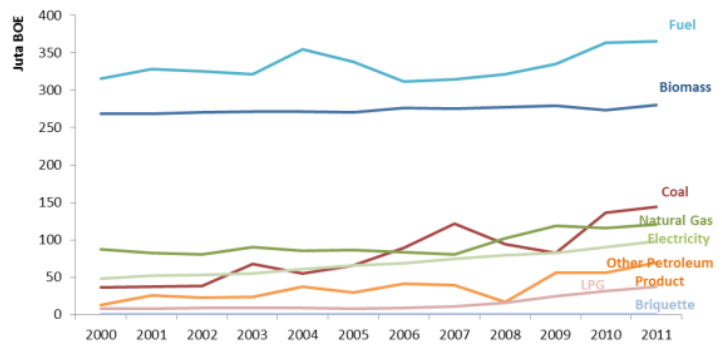

Gambar 2. Konsumsi energi final per jenis energi 2000-2010 (Sumber: Kementrian ESDM,2012)

Setiap tahunnya, penggunaan energi untuk sektor transportasi merupakan sektor terbesar kedua setelah sektor industri dibandingkan dengan sektor-sektor lainnya seperti rumah tangga, komersial dan sektor lainnya. Tingginya kebutuhan pada sektor transportasi diiringi dengan peningkatan jumlah volume kendaraan yang dimiliki. Peningkatan volume kendaraan tersebut dapat disebabkan oleh banyak hal antara lain jarak tempat tinggal yang semakin jauh dengan tempat kerja atau sekolah, orang lebih tertarik untuk memiliki kendaraan pribadi karena angkutan umum yang ada dirasa belum nyaman dan sebagainya. Data mengenai pemakaian energi per sektor dapat dilihat pada gambar 3.

Bila penggunaan minyak bumi semakin meningkat dalam jumlah besar dan tidak dihasilkannya cadangan minyak baru, maka bisa saja minyak bumi akan habis sebelum 
dapat diperbaharui kembali. Maka dari itu, perlu dipikirkan untuk membuat sebuah konsep kendaraan masa depan yang tidak menggunakan bahan bakar minyak, ramah lingkungan dan dilengkapi dengan sistem pintar ataupun berteknologi tinggi untuk mencegah terjadinya kecelakaan sehingga dapat mengurangi angka kecelakaan akibat kesalahan manusia saat mengemudi.

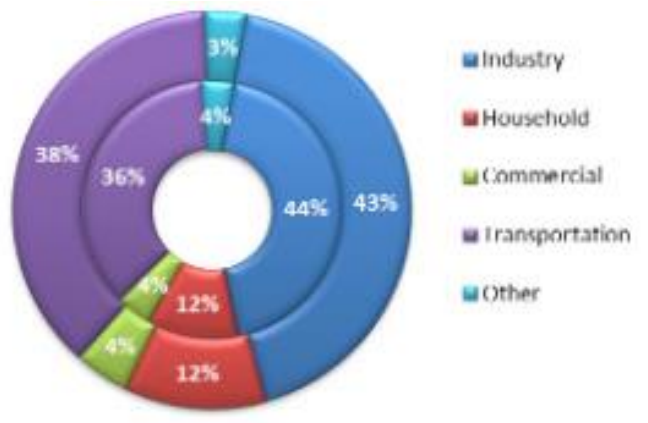

Gambar 3. Konsumsi penggunaan energi final berdasarkan sektor 2010-2011 (Sumber: Kementrian ESDM,2012)

Pada penelitian ini akan dibuat masterplan sistem sebuah mobil yang dapat membantu menyelesaikan permasalahan diatas menggunakan konsep system engineering. Konsep system engineering digunakan karena system engineering merupakan pendekatan interdisiplin yang dapat merealisasikan sistem yang sukses dan proses pengembangan dilakukan secara terstruktur mulai dari konsep, produksi hingga operasi dari sebuah sistem. Sistem yang menjadi objek adalah sistem buatan manusia, dibuat dan digunakan untuk menyediakan produk atau jasa yang ditujukan untuk dapat memberi manfaat kepada pengguna dan semua stakeholder terkait. (International Council on System Engineering, 2015). Mobil dipilih karena mobil merupakan kendaraan multi-fungsi yang diminati oleh masyarakat Indonesia karena dapat mengangkut barang dalam jumlah yang banyak dan dapat mengangkut seluruh anggota keluarga yang besar.

\section{Studi Literatur}

Studi literatur yang dilakukan mengenai teknologi green car dan mobil masa depan serta studi literatur mengenai system engineering dari INCOSE.

\section{Teknologi Green Car dan Mobil Masa Depan}

Menurut survey yang dilakukan oleh Zhang dan Cooke, teknologi green car yang ada saat ini adalah
1. Pure electric car, yaitu mobil yang hanya menggunakan baterai sebagai sumber energinya.

2. Hybrid car, yaitu mobil yang sumber energinya berasal dari listrik dan bahan bakar minyak.

3. Plug-in hybrid car, mirip dengan hybrid car, hanya saja pada plug-in hybrid car, pengisian listrik dapat dilakukan pada stopkontak didalam rumah.

4. Hydrogen fuel cells, menggunakan baterai yang digerakkan oleh gas hidrogen untuk menghasilkan listrik. Namun teknologi mobil hydrogen fuel cells masih sangat mahal.

Sedangkan untuk beberapa teknologi mobil masa depan adalah sebagai berikut (Forbes, 2015):

1. Material Badan Mobil, saat ini sedang dikembangkan material daur ulang untuk badan mobil. Material yang berhasil dikembangkan adalah biofibre, merupakan material yang dapat didaur ulang, ringan dan memiliki kekuatan yang tidak kalah dari bahan karbon fiber.

2. Sistem autonomous, sistem ini memungkinkan mobil mengemudi dengan sendirinya. Mobil dapat mengemudi menggunakan perangkat kamera, sensor, radar, laser dan GPS. Pada tahun 2020 diperkirakan teknologi ini sudah baik.

3. Sistem driver override, sistem ini dapat membuat mobil membuat keputusannya sendiri, semisal saat kita lupa menekan rem, maka mobil akan mengatur dirinya sendiri untuk melakukan pengereman dalam keadaan darurat.

\section{System Engineering}

Menurut International Council on System Engineering (INCOSE) (2015), system engineering adalah sebuah pendekatan interdisiplin yang bertujuan untuk merealisasikan sebuah sistem yang sukses. System engineering fokus pada pendefinisian kebutuhan konsumen dan membutuhkan lintas disiplin ilmu diawal tahap pengembangan, pendokumentasian kebutuhan, dan kemudian dilanjutkan dengan perancangan dan validasi sistem dengan mempertimbangkan keseluruhan permasalahan: operasi, biaya, jadwal, performansi, pelatihan dan pendukung, pengujian, produksi dan disposal. System 
engineering mengintegrasikan semua disiplin ilmu dan sebuah grup khusus ke dalam tim pembentukan proses pengembangan yang terstruktur mulai dari konsep, produksi hingga operasi dari sebuah sistem. System engineering mempertimbangkan baik kebutuhan bisnis dan kebutuhan teknis dari semua konsumen dengan tujuan untuk menyediakan produk berkualitas yang dapat memenuhi kebutuhan pengguna.

Sistem yang dimaksud disini adalah sebuah kumpulan elemen yang terintegrasi yang memiliki tujuan tertentu. Elemen-elemen disini termasuk produk (hardware, software, firmware), proses, orang, informasi, metode, fasilitas, layanan, dan elemen pendukung lainnya. Sistem yang menjadi objek adalah sistem buatan manusia, dibuat dan digunakan untuk menyediakan produk atau jasa yang ditujukan untuk dapat memberi manfaat kepada pengguna dan semua stakeholder terkait. Proses didalam system engineering adalah technical processes, technical management processes, agreement processes dan organizational project-enabling processes.

\section{Metodologi Penelitian}

Penelitian ini menggunakan konsep system engineering dari INCOSE (International Council on System Engineering) untuk membuat masterplan sistem smart green car di Indonesia pada tahun 2025 yang terdiri dari identifikasi kebutuhan, identifikasi stakeholder, concept of operations, stakeholder requirements dan system architecting.

\section{Identifikasi Kebutuhan}

Berdasarkan latar belakang yang telah diuraikan, maka diperlukan suatu konsep mobil masa depan yang menggunakan bahan bakar yang dapat diperbaharui, ramah lingkungan, dan dilengkapi dengan sistem pintar ataupun berteknologi tinggi yang dapat mencegah kecelakaan lalu lintas akibat kesalahan manusia saat mengemudi.

\section{Pembentukan Ide}

Berdasarkan identifikasi kebutuhan diatas maka akan dikembangkan suatu mobil masa depan ramah lingkungan dengan konsep "Non Unrenewable Resources Car" bernama SGC (Smart Green Car) dengan spesifikasi umum sebagai berikut:
1. Sumber energi SGC

Sumber energi yang akan digunakan untuk SGC adalah energi listrik yang berasal dari baterai. Energi listrik digunakan karena energi listrik menghasilkan emisi gas buang yang sangat kecil dibandingkan dengan menggunakan bahan bakar minyak sehingga dapat mengurangi polusi udara. Energi listrik pada baterai didapatkan dari stop kontak listrik dirumah ataupun di stasiun pengisian baterai maupun dari cahaya matahari dengan menggunakan photovoltaic. Baterai pada SGC akan dibuat dengan teknologi pengisian yang cepat dan terdapat stasiun pengisian baterai seperti layaknya SPBU saat ini. Sumber listrik pengisian baterai berasal dari PLTA dan cahaya matahari yang ditangkap oleh panel surya.

2. Spesifikasi fisik mobil

\section{a. Size flexibility}

Ukuran mobil SGC dapat disesuaikan dengan penggunaannya. Jika penumpang dalam mobil sedikit maka ukuran mobil dapat diatur pada mode pendek (2 baris tempat duduk) sementara saat penumpang banyak maka ukuran mobil dapat diatur pada mode panjang ( 3 baris tempat duduk). Size flexibility dibuat dengan tujuan untuk mengurangi kemacetan dengan menyesuaikan ukuran mobil dengan jumlah penumpang yang ada.

b. Mesin

Mesin yang digunakan adalah mesin yang berkapasitas cc rendah tetapi tetap bertenaga. Kapasitas cc rendah dipilih dengan tujuan efisiensi energi agar baterai tidak cepat habis saat digunakan.

c. Material badan mobil

Efisiensi energi juga dapat diperoleh dengan membuat mobil lebih ringan. Salah satu caranya adalah dengan menggunakan material badan mobil berbahan ringan dan dapat didaur ulang.

3. Keselamatan dan keamanan

Untuk meminimalkan kecelakaan akibat kesalahan manusia, cara pengemudian SGC dibagi menjadi 2 yaitu autonomous dimana mobil dapat menyetir sendiri tanpa arahan dari manusia dan pengemudian secara manual. SGC nantinya juga dilengkapi dengan full air-bag pada semua sisi mobil dan beberapa sensor keselamatan serta dilengkapi dengan teknologi GPS. Fitur 
keamanan untuk mencegah SGC dari tindak pencurian adalah dengan adanya alarm yang terhubung dengan gadget pemilik dan menggunakan sistem fingerprint.

\section{Identifikasi Stakeholder}

Pada tahap ini akan ditentukan siapa saja yang menjadi stakeholder dalam sistem smart green car yang akan dibangun. Stakeholder untuk sistem SGC adalah sebagai berikut:

\section{Konsumen SGC}

merupakan stakeholder yang berperan sebagai pengguna SGC.

2. Kementrian perhubungan

merupakan stakeholder yang memiliki sistem dan sebagai pendukung keputusan.

3. SPB (Stasiun Pengisian Baterai)

Merupakan stakeholder yang berfungsi mendukung system SGC.

4. Produsen SGC merupakan stakeholder yang bertanggung jawab dalam pembuatan SGC

5. Produsen baterai merupakan stakeholder yang bertanggung jawab dalam pembuatan baterai SGC sebagai sumber energi listrik SGC.

6. Showroom SGC

Merupakan stakeholder yang bertanggung jawab untuk memasarkan dan menjual SGC kepada masyarakat

7. PLN

merupakan stakeholder yang bertanggung jawab untuk menghasilkan dan memasok listrik kepada SPB.

8. Bengkel perawatan SGC

Merupakan stakeholder yang mendukung sebagai sarana perawatan SGC

9. Pemerintah merupakan stakeholder yang mengeluarkan peraturan, kebijakan dan persetujuan terhadap sistem SGC.

10. Masyarakat umum

Merupakan stakeholder yang secara tidak langsung berdampak karena adanya system SGC.

\section{Context Diagram}

Setelah ditentukan siapa saja stakeholder dalam sistem SGC, maka dibuatlah context diagram untuk menunjukkan hubungan antara stakeholder dengan sistem SGC. Context diagram dapat dilihat didalam lampiran 1.

\section{Stakeholder Requirement}

Masing-masing stakeholder didalam sistem SGC memliki requirement-nya masing-masing dalam sistem SGC ini. Oleh karena itu dibutuhkan adanya penjabaran tentang requirement masing-masing stakeholder didalam sistem SGC agar nantinya sistem yang dibuat dapat diterima oleh semua stakeholder.

Requirement untuk stakeholder konsumen diperoleh dari hasil wawancara dengan pengguna mobil sebanyak 40 orang dengan sebelumnya pertanyaan didesain terlebih dahulu oleh tim pengembang SGC Stakeholder requirement yang lain didapatkan dari hasil brainstorming tim pengembang SGC berdasarkan berita terkait dengan rencana pemerintah untuk mencanangkan program mobil listrik nasional, kemudian kami sesuaikan dengan sistem SGC.

\section{Concept of Operations (ConOps)}

Concept of operations mendeskripsikan bagaimana suatu sistem bekerja dari sudut pandang pengguna (INCOSE, 2015). ConOps menjadi penghubung antara kebutuhan operasional pengguna sistem dan spesifikasi teknis dari perancang sistem. Gambar ConOps dari sistem SGC dapat dilihat pada lampiran 5 dengan deskripsi sebagai berikut:

1. Produsen SGC memproduksi SGC sesuai dengan requirement dari stakeholder dan baterainya berasal dari pabrik baterai SGC.

2. Mobil yang telah diproduksi dikirimkan ke showroom dan konsumen membeli SGC melalui showroom.

3. Jika dalam penggunaan baterai habis, pengguna dapat langsung membawa SGC ke SPB untuk dilakukan penukaran baterai kosong dengan baterai yang telah terisi (baterai kosong akan diisi ulang oleh pihak SPB). SGC juga dapat melakukan pengisian ulang listrik sendiri melalui panel surya yang terdapat diatap SGC.

4. Jika dalam penggunaan SGC mengalami kerusakan atau kendala maka pengguna dapat membawa SGC ke bengkel-bengkel SGC yang tersedia di showroom maupun yang berada didekat SPB.

5. Setelah masa pakai SGC sudah selesai (disposal) maka SGC akan ditarik kembali oleh produsen SGC untuk dilakukan daur ulang. 


\section{Core Functional Matrix}

Seluruh requirement masing-masing stakeholder yang didapatkan dari tahap identifikasi stakeholder requirement dimasukkan kedalam core functional matrix untuk mendapatkan requirement yang penting untuk dimasukkan ke dalam sistem SGC. Requirement yang tidak begitu penting menurut core functional matrix tidak dimasukkan ke dalam requirement sistem. Tingkat kepentingan diperoleh dari pembobotan masing-masing requirement terhadap masing-masing stakeholder. Bobot tersebut lalu dijumlahkan untuk setiap requirement sehingga didapatkan bobot untuk setiap requirement. Bobot kepentingan yang digunakan adalah $\mathrm{P}=$ Primary (berbobot 3), $\mathrm{S}=$ Secondary (memiliki bobot 2) dan $\mathrm{X}=$ Not Important (memiliki bobot 1). Core Functional matrix dapat dilihat pada lampiran 2. Dari hasil core functional matrix terpilih 33 requirement dari 42 requirement yang akan dimasukkan kedalam QFD.

\section{Quality Function Deployment (QFD)}

Menurut Liansari (2016) setelah dilakukan identifikasi kebutuhan konsumen baru kemudian kebutuhan ini dapat dianalisis ke dalam QFD. Kebutuhan konsumen pada penelitian ini berupa kebutuhan dari para stakeholder sehingga stakeholder requirement terpilih pada hasil core functional matrix kemudian dimasukkan kedalam QFD untuk mengetahui fitur apa yang diinginkan oleh stakeholder yang harus ada atau penting didalam sistem SGC. QFD dapat dilihat pada lampiran 3.. QFD menunjukkan bahwa terdapat 13 fitur yang harus ada dalam sistem SGC dari yang semula berjumlah 17 fitur. Ke-13 fitur tersebut adalah:

1. Pemasangan baterai maksimum 2 menit

2. Baterai dapat diisi penuh dalam waktu 30 menit

3. Size Flexibility (5 sampai 8 seat)

4. Melindungi dari kecelakaan

5. Ramah lingkungan (tingkat polusi)

6. Energi baterai dapat digunakan sejauh 300 $\mathrm{Km}$

7. Dapat menanjak pada muatan penuh

8. Produksi massal

9. PLN yang handal

10. Stasiun pengisian baterai yang mudah ditemui

11. Bengkel yang mudah ditemui

12. Self-charging
13. Suku cadang yang mudah didapatkan Sedangkan 4 fitur yang tereduksi adalah :

1. Melindungi dari pencurian

2. Mencegah kecelakaan

3. Bahan ramah lingkungan

4. Showroom yang mudah ditemui

Dengan beberapa pertimbangan dari tim pengembang SGC bahwa fitur mencegah kecelakaan dan melindungi dari pencurian tetap dimasukkan kedalam sistem SGC.

\section{System Architecture}

Berdasarkan hasil dari QFD maka dibuatlah masterplan untuk sistem SGC yaitu sebuah sistem mobil masa depan ramah lingkungan dengan komponen sistem sebagai berikut:

1. Mobil SGC (spesifikasi dapat dilihat pada lampiran 4).

a. Sumber energi

SGC menggunakan energi listrik yang berasal dari baterai sebagai sumber energinya. Energi listrik pada baterai bersumber dari stop kontak listrik maupun dari cahaya matahari. Pengisian baterai melalui cahaya matahari dapat dilakukan sendiri dengan menggunakan panel surya yang dipasang pada atap mobil menggunakan photovoltaic cells (PVC) yang dapat mengubah energi dari cahaya matahari langsung menjadi energi istrik. Selain itu dapat pula dilakukan pengisian baterai dengan stop kontak dirumah atau di stasiun pengisian baterai.

b. Bentuk mobil

Ukuran SGC dapat disesuaikan dengan penggunaannya (size flexibility). Jika penumpang dalam mobil sedikit maka kita dapat mengaktifkan mode pendek (maksimal 5 penumpang) sementara jika penumpang dalam mobil banyak maka mobil akan menjadi mode panjang (maksimal 8 penumpang). Panjang pendek mobil dapat diatur dengan menekan tombol didalam mobil.

c. Material body mobil

Material yang digunakan adalah biofibre yang merupakan bahan yang dapat didaur ulang serta ringan dan memiliki kekuatan yang sama dengan serat karbon. Tujuannya agar membuat mobil lebih ringan sehingga dapat membuat penggunaan energi lebih efisien.

d. Mesin mobil

Mesin mobil SGC menggunakan mesin berkapasitas 1200 cc karena menurut 
Kementrian Perindustrian Republik Indonesia bahwa Low Cost Green Car adalah mobil dengan kapasitas mesin 1.000 cc - 1200 cc. 1200 cc dipilih agar tenaga yang dihasilkan SGC cukup besar untuk mengangkut 8 penumpang.

\section{e. Baterai}

Baterai yang digunakan adalah aluminium air battery yang dalam kondisi penuh dapat menempuh jarak 1000 miles, lebih ringan, dapat didaur ulang, proses pengisian lebih cepat dibanding dengan lithium-ion battery.

f. Sistem kemudi

Sistem kemudi SGC menggunakan sistem autonomous dimana mobil dapat menyetir sendiri tanpa arahan dari manusia, SGC juga dapat dikemudikan secara manual.

g. Keselamatan

SGC dilengkapi dengan dengan sistem dual, side dan curtain air bag yang akan mengembang secara otomatis jika ada benturan yang keras sehingga dapat melindungi penumpang baris depan ataupun baris belakang dari benturan saat terjadi kecelakaan. SGC juga dilengkapi dengan beberapa sensor keselamatan yaitu LKAS (sensor yang akan memberi peringatan kepada pengemudi saat mobil keluar dari lintasannya secara mendadak), LDW (sensor yang akan secara otomatis mengembalikan posisi mobil ke lintasan yang seharusnya) dan AEB (sistem pengereman dimana mobil akan secara otomatis melakukan pengereman jika pengemudi belum melakukan pengereman pada jarak tertentu).

2. Stasiun pengisian baterai

Stasiun pengisian baterai merupakan tempat dimana baterai-baterai ditukar dan diisi ulang. Konsepnya adalah jika level baterai mobil sudah rendah dan tidak memungkinkan untuk diisi ulang karena cuaca mendung sehingga tidak ada cahaya matahari ataupun melakukan perjalanan jauh maka pengendara dapat mengunjungi SPB untuk menukarkan baterai yang habis dengan baterai yang terisi penuh sehingga tidak diperlukan waktu yang lama untuk mendapatkan kembali energi listrik. Baterai kosong yang telah ditukarkan kemudian akan diisi ulang oleh petugas SPB untuk kemudian dapat ditukarkan kembali. Lokasi SPB akan dibangun di lokasi-lokasi SPBU yang sudah ada saat ini.

3. Pabrik SGC

Agar SGC dapat digunakan secara massal maka SGC perlu diproduksi secara massal. Penyediaan pabrik akan ditawarkan kepada pihak pemerintah atau swasta. Pabrik SGC juga nantinya akan memproduksi suku cadang SGC untuk didistribusikan ke bengkel-bengkel SGC diseluruh Indonesia.

4. Bengkel SGC

Bengkel-bengkel SGC akan dibangun diseluruh kota dan daerah di Indonesia agar masyarakat dapat dengan mudah untuk melakukan perawatan maupun pergantian suku cadang dari SGC. Bengkel SGC juga ada yang berlokasi bersamaan dengan dealer SGC.

5. Pabrik baterai SGC

Penyediaan pabrik baterai akan ditawarkan kepada pemerintah atau swasta untuk melakukan produksi baterai secara massal dan kemudian baterai didistribusikan ke pabrik SGC, SPB dan bengkel SGC.

6. Dealer penjualan SGC

SGC yang sudah diproduksi kemudian akan dijual kepada konsumen melalui dealer-dealer penjualan yang berlokasi diseluruh Indonesia.

7. Pendukung sistem SGC

a. Uji Kelayakan

SGC perlu dilakukan uji kelayakan yang mencakupi uji keselamatan dan uji emisi gas buang.

b. Program untuk mensukseskan SGC Untuk mensukseskan sistem SGC dapat dilakukan dengan dengan membatasi penjualan kendaraan berbahan bakar minyak, penggunaan SGC untuk mobil dinas, pajak kendaraan SGC yang lebih rendah dibandingkan kendaraan berbahan bakar minyak, dan harga yang lebih terjangkau.

c. Life Cycle System

SGC yang sudah memasuki tahap disposal akan ditarik dan dibeli kembali oleh pabrik produksi SGC untuk didaur ulang menjadi produk SGC baru.

\section{Kesimpulan}

Dalam penelitian ini dibuat masterplan sebuah sistem transportasi smart green car di 
Indonesia pada tahun 2025 dengan menggunakan konsep system engineering dari INCOSE (International Council on System Engineering). Pembuatan konsep dimulai dari identifikasi kebutuhan, identifikasi stakeholder (context diagram), concept of operations (ConOps), stakeholder requirements (core functional matrix dan QFD) dan system architecting.

\section{Daftar Pustaka}

Asril, S., 90 Persen Kecelakaan karena Faktor Manusia, [Online], Diakses dari: http://megapolitan.kompas.com/read/2012/ 07/26/10303566/90.Persen.Kecelakaan.kar ena.Faktor.Manusia [2017, 21 Februari].

Badan Pusat Statistik., Perkembangan Jumlah Kendaraan Bermotor Menurut Jenis Tahun 1987-2013, [Online], Diakses dari: https://www.bps.go.id/linkTabelStatis/view/i d/1413 [2017, 24 Februari].

Forbes., Top 10 Advanced Car Technologies by 2020, [online], Diakses dari: https://www.forbes.com/sites/kbrauer/2015/ 01/19/top-10-advanced-car-technologiesby-2020/\#3b6266026705 [2017, 22 Februari].

INCOSE. (2015). System Engineering Handbook: A Guide For System Life Cycle Processes and Activities (4th ed.). New Jersey: John Wiley \& Sons.

Kementrian ESDM., Kajian Supply and Demand Energy, [Online], Diakses dari: http://prokum.esdm.go.id/Publikasi/Hasil\%2 OKajian/ESDM\%20SDE.pdf [2017, 21 Februari].

Kementrian ESDM., Statistik Minyak Bumi, [Online], Diakses dari: http://prokum.esdm.go.id/Publikasi/Statistik/ Statistik\%20Minyak\%20Bumi.pdf [2017, 21 Februari].

Liansari, G.P., Novirani D., Subagja, R.N. (2016). Rancangan Blueprint Alat Cetak Kue Balok yang Ergonomis dengan Metode Ergonomic Function Deployment (EFD). Jurnal Rekayasa Sistem Industri. Vol 5(2).

Setiawan, D., Data Terkini, Jumlah Penduduk Indonesia 257,9 Juta, yang Wajib KTP 182,5 Juta, [Online], Diakses dari: http://jateng.tribunnews.com/2016/09/01/dat a-terkini-jumlah-penduduk-indonesia-2579juta-yang-wajib-ktp-1825-juta [2017, 24 Februari]. 
Lampiran 1. Context diagram

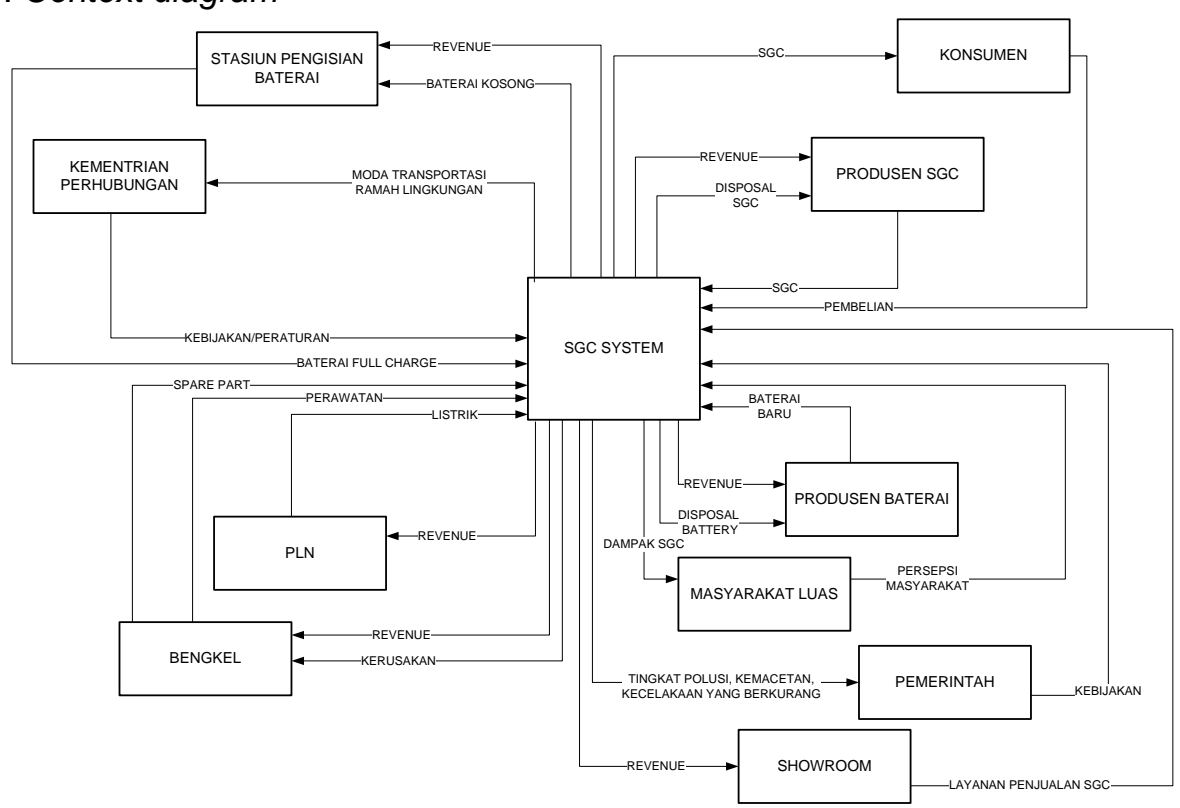

Lampiran 2. Core functional matrix

\begin{tabular}{|c|c|c|c|c|c|c|c|c|c|c|c|}
\hline & & \multicolumn{10}{|c|}{ Core Functionality Matrix } \\
\hline & & Konsumen & $\begin{array}{l}\text { Kementrian } \\
\text { Perhubungan }\end{array}$ & $\begin{array}{c}\text { Stasiun } \\
\text { Pengisian } \\
\text { Baterai }\end{array}$ & Produsen SGC & Produsen Baterai & $\begin{array}{l}\text { Showroom } \\
\text { SGC }\end{array}$ & PLTA & $\begin{array}{c}\text { Bengkel } \\
\text { perawatan SGC }\end{array}$ & Pemerintah & $\begin{array}{l}\text { Masyarakat } \\
\text { Umum }\end{array}$ \\
\hline 1 & Tidak akan terjadi konsleting & $P$ & $x$ & $\mathrm{P}$ & $P$ & $P$ & $\mathrm{~s}$ & $x$ & $\mathrm{p}$ & $x$ & $\mathrm{~s}$ \\
\hline 2 & Energi listrik mudah dicari & $p$ & $x$ & $p$ & $\mathrm{~s}$ & $\mathrm{p}$ & $\mathrm{s}$ & $p$ & $\mathrm{~s}$ & $x$ & $x$ \\
\hline 3 & Proses charging baterai cepat dan mudah & $P$ & $x$ & $P$ & $\mathrm{~s}$ & $P$ & $\mathrm{~s}$ & $x$ & $P$ & $x$ & $x$ \\
\hline 4 & Spare part mudah ditemukan & $\mathrm{P}$ & $x$ & $\mathrm{~s}$ & $P$ & $\mathrm{~s}$ & $P$ & $x$ & $P$ & $x$ & $x$ \\
\hline 5 & Bengkel perawatan mudah ditemukan & $\mathrm{p}$ & $x$ & $\mathrm{~s}$ & $\mathrm{p}$ & $P$ & $P$ & $x$ & $p$ & $x$ & $x$ \\
\hline 6 & Adanya stasiun pengisian bahan bakar energi & $p$ & $P$ & $p$ & $p$ & $p$ & $p$ & $p$ & $P$ & $P$ & $x$ \\
\hline 7 & Self-charging & $P$ & $x$ & $P$ & $P$ & $P$ & $P$ & $\mathrm{~s}$ & $P$ & $\mathrm{~s}$ & $x$ \\
\hline 8 & Performa baterai tahan lama & $\mathrm{p}$ & $P$ & $\mathrm{p}$ & $P$ & $p$ & $\mathrm{p}$ & $p$ & $\mathrm{~s}$ & $p$ & $x$ \\
\hline 9 & Mobil jenis MPV & $p$ & $\mathrm{~s}$ & $x$ & $p$ & $P$ & $\mathrm{~s}$ & $\mathrm{x}$ & $\mathrm{s}$ & $\mathrm{P}$ & $x$ \\
\hline 10 & Jumlah tempat duduk 5 sd 8 orang & $P$ & $P$ & $x$ & $P$ & $P$ & $\mathrm{~s}$ & $x$ & $P$ & $P$ & $x$ \\
\hline 11 & $\begin{array}{l}\text { Sistem keamanan menggunakan data pribadi } \\
\text { pemilik }\end{array}$ & $\mathrm{P}$ & $x$ & $x$ & $\mathrm{P}$ & $x$ & $x$ & $\mathrm{x}$ & $x$ & $\mathrm{P}$ & $\mathrm{x}$ \\
\hline 12 & Sabuk pengaman yang nyaman & $\mathrm{P}$ & $x$ & $x$ & $\mathrm{~s}$ & $\mathrm{x}$ & $x$ & $\mathrm{x}$ & $x$ & $x$ & $x$ \\
\hline 13 & $\begin{array}{l}\text { Interior dalam mobil nyaman untuk berpergian } \\
\text { jarak jauh }\end{array}$ & $\mathrm{p}$ & $x$ & $x$ & s & $x$ & $x$ & $x$ & $x$ & $\mathrm{x}$ & $x$ \\
\hline 14 & Auto-pilot (dapat berkendara sendiri) & $P$ & $P$ & $x$ & $P$ & $\mathrm{~s}$ & $P$ & $x$ & $P$ & $P$ & $x$ \\
\hline 15 & $\begin{array}{l}\text { Sensor untuk indikator keselamatan berkendara } \\
\text { diperbanyak }\end{array}$ & $\mathrm{p}$ & $\mathrm{P}$ & $x$ & $\mathrm{P}$ & $\mathrm{s}$ & $\mathrm{p}$ & $\mathrm{x}$ & $\mathrm{p}$ & $\mathrm{P}$ & $\mathrm{x}$ \\
\hline 16 & \begin{tabular}{|l|} 
Bahan bakar yang digunakan adalah ramah \\
lingkungan
\end{tabular} & $\mathrm{P}$ & $\mathrm{p}$ & $\mathrm{p}$ & $\mathrm{P}$ & $\mathrm{P}$ & $\mathrm{s}$ & $\mathrm{P}$ & $\mathrm{p}$ & $\mathrm{P}$ & $\mathrm{P}$ \\
\hline 17 & $\begin{array}{l}\text { Haga beli mobil berkisar antara Rp } 201.000 .000 \text { sd } \\
\text { Rp } 300.0000\end{array}$ & $\mathrm{p}$ & $\mathrm{p}$ & $x$ & $\mathrm{p}$ & s & $\mathrm{p}$ & $x$ & s & $\mathrm{p}$ & $x$ \\
\hline 18 & SGC didesain dapat mengurangi kemacetan & $p$ & $P$ & $x$ & $P$ & $x$ & $p$ & $x$ & $p$ & $p$ & $P$ \\
\hline 19 & SGC dapat mengurangi polusi (ramah lingkungan) & $\mathrm{P}$ & P & $x$ & $\mathrm{P}$ & $x$ & $\mathrm{P}$ & $\mathrm{x}$ & p & p & $\mathrm{p}$ \\
\hline 20 & SGC dapat digunakan oleh masyarakat luas & $P$ & $P$ & $\mathrm{P}$ & $P$ & $\mathrm{P}$ & $P$ & $\mathrm{~s}$ & $P$ & $P$ & $\mathrm{~s}$ \\
\hline 21 & SGC dapat mengurangi tingkat kecelakaan & $P$ & $P$ & $x$ & $P$ & $x$ & $P$ & $x$ & $\mathrm{~s}$ & $P$ & $P$ \\
\hline 22 & \begin{tabular}{|l|} 
Proses pengisian energi listrik SGC tidak sulit \\
\end{tabular} & $p$ & $x$ & $P$ & $P$ & $P$ & $P$ & $\mathrm{~s}$ & $x$ & $P$ & $x$ \\
\hline 23 & Proses pengisian energi listrik SGC cepat & $P$ & $x$ & $P$ & $P$ & $P$ & $P$ & $\mathrm{~s}$ & $x$ & $P$ & $x$ \\
\hline 24 & Proses distribusi listrik dari PLTA mudah & $\mathrm{P}$ & $x$ & $\mathrm{p}$ & $\mathrm{p}$ & $\mathrm{P}$ & $\mathrm{P}$ & $\mathrm{s}$ & $x$ & $\mathrm{p}$ & $x$ \\
\hline 25 & Proses distibusi listrik dai PLTA cepat & $\mathrm{P}$ & $x$ & $\mathrm{P}$ & $p$ & $\mathrm{p}$ & $\mathrm{p}$ & s & $x$ & $\mathrm{p}$ & $\mathrm{x}$ \\
\hline 26 & $\begin{array}{l}\text { Lokasi SPB berada ditempat yang mudah } \\
\text { dijangkau bagi konsumen SGC }\end{array}$ & $\mathrm{P}$ & $\mathrm{P}$ & $\mathrm{p}$ & $\mathrm{s}$ & $\mathrm{s}$ & $\mathrm{P}$ & $\mathrm{P}$ & $\mathrm{x}$ & $\mathrm{P}$ & $x$ \\
\hline 27 & SGC dapat diterima di masyarakat & $\mathrm{s}$ & $P$ & $P$ & $P$ & $p$ & $P$ & $\mathrm{~s}$ & $P$ & $P$ & $\mathrm{~s}$ \\
\hline 28 & $\begin{array}{l}\text { Desain SGC bisa direalisasikan di lantai produksi } \\
\text { dengan produksi massal }\end{array}$ & $\mathrm{s}$ & $\mathrm{P}$ & $\mathrm{p}$ & $\mathrm{P}$ & $\mathrm{p}$ & $\mathrm{p}$ & $\mathrm{x}$ & s & $\mathrm{p}$ & $\mathrm{x}$ \\
\hline 29 & Baterai yang ringan & $\mathrm{s}$ & $x$ & $\mathrm{p}$ & $\mathrm{p}$ & $\mathrm{p}$ & 5 & $x$ & $\mathrm{~s}$ & $x$ & $x$ \\
\hline 30 & Baterai yang mudah dipasang & $P$ & $x$ & $\mathrm{P}$ & $P$ & $P$ & $\mathrm{~s}$ & $x$ & $\mathrm{~s}$ & $x$ & $x$ \\
\hline 31 & $\begin{array}{l}\text { Material untuk produksi mobil dapat didaur ulang } \\
\text { bila umur pakai } S G C \text { telah habis }\end{array}$ & $\mathrm{s}$ & $\mathrm{s}$ & $x$ & $\mathrm{p}$ & $\mathrm{s}$ & $\mathrm{x}$ & $x$ & $\mathrm{x}$ & $\mathrm{p}$ & $\mathrm{s}$ \\
\hline 32 & $\begin{array}{l}\text { Biaya produksi dapat ditekan seminimal mungkin } \\
\text { namun tetap dengan kualitas yang baik }\end{array}$ & s & $x$ & $x$ & $\mathrm{P}$ & s & $\mathrm{P}$ & $x$ & $x$ & $x$ & $x$ \\
\hline 33 & $\begin{array}{l}\text { Material baterai dapat didaur ulang bila umur } \\
\text { pakai baterai telah habis. }\end{array}$ & $x$ & $\mathrm{~s}$ & $x$ & $\mathrm{~s}$ & $\mathrm{p}$ & $x$ & $x$ & $\mathrm{x}$ & $\mathrm{s}$ & $\mathrm{x}$ \\
\hline 34 & $\begin{array}{l}\text { Baterai yang digunakan oleh SGV hanya berasal } \\
\text { dari supplier tunggal }\end{array}$ & $x$ & $x$ & $\mathrm{~s}$ & $\mathrm{P}$ & $\mathrm{P}$ & $\mathrm{x}$ & $\mathrm{x}$ & $x$ & $x$ & $x$ \\
\hline 35 & Persediaan SGC stabil & $p$ & $P$ & $P$ & $p$ & $p$ & $p$ & $x$ & $\mathrm{x}$ & $P$ & $\mathrm{~s}$ \\
\hline 36 & Persediaan $S G C$ yang cepat terpenuhi & $\mathrm{p}$ & $P$ & $\mathrm{p}$ & $\mathrm{P}$ & $\mathrm{P}$ & $P$ & $x$ & $x$ & $P$ & $\mathrm{~s}$ \\
\hline 37 & Mobil yang laku terjual dipasaran & $\mathrm{s}$ & $P$ & $P$ & $P$ & $\mathrm{~s}$ & $\mathrm{P}$ & $x$ & $\mathrm{~s}$ & $\mathrm{~s}$ & $x$ \\
\hline 38 & Pengiriman mobil yang tepat waktu & $P$ & $\mathrm{~s}$ & $\mathrm{~s}$ & $P$ & $x$ & $P$ & $x$ & $x$ & $x$ & $x$ \\
\hline 39 & $\begin{array}{l}\text { Ketersediaan air dan bendungan yang mencukupi } \\
\text { untuk menghasilkan listrik }\end{array}$ & $\mathrm{P}$ & $\mathrm{s}$ & $\mathrm{p}$ & $\mathrm{P}$ & $x$ & s & $\mathrm{P}$ & $\mathrm{x}$ & $\mathrm{s}$ & $x$ \\
\hline 40 & \begin{tabular}{|l}
$\begin{array}{l}\text { Lokasi bengkel berada di tempat yang mudah } \\
\text { dijangkau oleh konsumen }\end{array}$ \\
\end{tabular} & $\mathrm{P}$ & $\mathrm{x}$ & $x$ & $\mathrm{P}$ & $\mathrm{P}$ & $\mathrm{P}$ & $\mathrm{x}$ & $\mathrm{p}$ & $x$ & $\mathrm{x}$ \\
\hline 41 & $\begin{array}{l}\text { Spare part dan perlengkapan maintenance di } \\
\text { sediakan oleh bengkel SGC }\end{array}$ & $\mathrm{P}$ & $x$ & $\mathrm{x}$ & $\mathrm{P}$ & $\mathrm{p}$ & $\mathrm{P}$ & $\mathrm{x}$ & $\mathrm{P}$ & $x$ & $\mathrm{x}$ \\
\hline 42 & $\begin{array}{l}\text { Material SGC dapat didaur ulang jika umur pakai } \\
\text { telah habis }\end{array}$ & $\mathrm{P}$ & $\mathrm{p}$ & $\mathrm{x}$ & $\mathrm{P}$ & $\mathrm{s}$ & $\mathrm{P}$ & $\mathrm{x}$ & $\mathrm{x}$ & $\mathrm{p}$ & $x$ \\
\hline
\end{tabular}


Lampiran 3. Quality function deployment

Customer Attributes, Needs,

Requirements, or Demanded Quality

\begin{tabular}{|l}
\hline Tidak akan terjadi konsleting \\
\hline Energi listrik mudah didapatkan
\end{tabular}

Proses charging baterai cepat dan mudah

Spare part mudah ditemukan

Bengkel perawatan mudah ditemukan

Adanya stasiun pengisian bahan bakar energi

Self-charging

Performa baterai tahan lama

Mobil jenis MPV

Jumlah tempat duduk $5 \mathrm{sd} 8$ orang

Auto-pilot (dapat berkendara sendiri)

Sensor untuk indikator keselamatan berkendara diperbanyak

Bahan bakar yang digunakan adalah ramah lingkungan

Haga beli mobil berkisar antara Rp 201.000.000 sd Rp 300.0000

SGC didesain dapat mengurangi kemacetan

SGC dapat mengurangi polusi (ramah lingkungan)

SGC dapat digunakan oleh masyarakat luas

SGC dapat mengurangi tingkat kecelakaan

Proses pengisian energi listrik SGC tidak sulit

Proses pengisian energi listrik SGC cepat

Proses distribusi listrik dari PLTA mudah

Proses distibusi listrik dai PLTA cepat

Lokasi SPB berada ditempat yang mudah dijangkau bagi konsumen

SGC

SGC dapat diterima di masyarakat

Desain SGC bisa direalisasikan di lantai produksi dengan produksi

massal

Baterai yang mudah dipasang

Persediaan SGC stabil

Persediaan SGC yang cepat terpenuhi

Mobil yang laku terjual dipasaran

Ketersediaan air dan bendungan yang mencukupi untuk menghasilkan

listrik

Lokasi bengkel berada di tempat yang mudah dijangkau oleh konsumen

Spare part dan perlengkapan maintenance di sediakan oleh bengkel

SGC

Material SGC dapat didaur ulang jika umur pakai telah habis
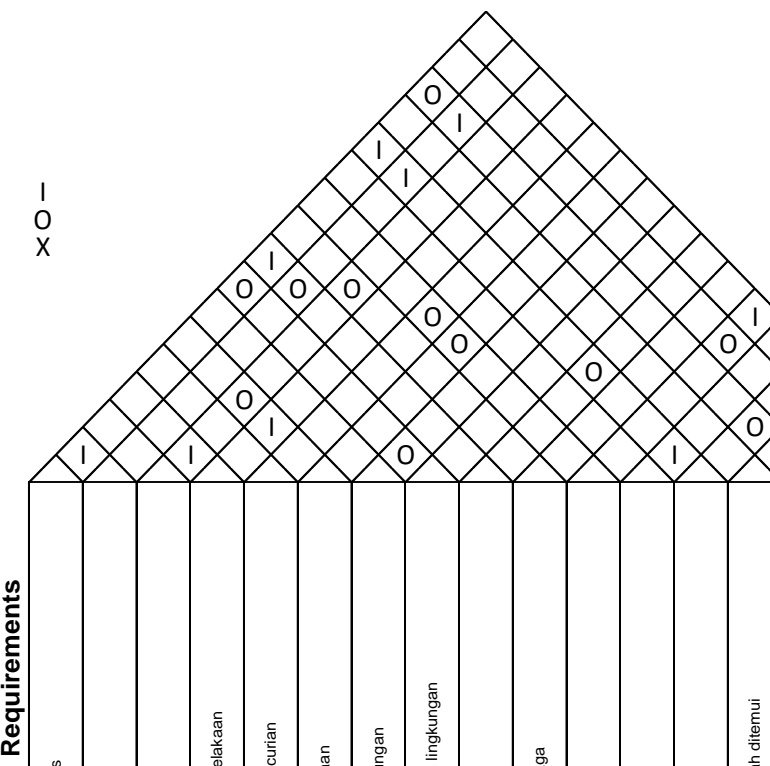

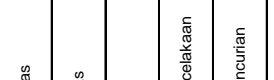
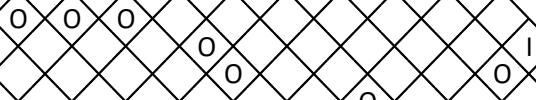

$\times 0 \times \times \times \times \times \times \times \times \times 1>$

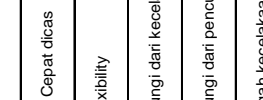


Lampiran 4. Spesifikasi mobil SGC

\begin{tabular}{|c|c|c|}
\hline No & Spesifikasi & Keterangan \\
\hline 1 & Sumber Energi & $\begin{array}{l}\text { Menggunakan energi listrik yang berasal dari baterai. Energi listrik } \\
\text { pada baterai dapat berasal dari stop kontak listrik maupun dari } \\
\text { cahaya matahari. Pengisian melalui cahaya matahari dapat dilakukan } \\
\text { sendiri dengan menggunakan panel surya yang dipasang pada atap } \\
\text { mobil menggunakan photovoltaic cells (PVC) yang dapat mengubah } \\
\text { energi dari cahaya matahari langsung menjadi energi listrik. Selain } \\
\text { itu dapat pula dilakukan pengisian baterai dengan stop kontak } \\
\text { dirumah atau di stasiun pengisian baterai. }\end{array}$ \\
\hline 2 & Bentuk Mobil & $\begin{array}{l}\text { Ukuran SGC dapat disesuaikan dengan penggunaannya (size } \\
\text { flexibility). Jika penumpang dalam mobil sedikit maka kita dapat } \\
\text { mengaktifkan mode pendek (maksimal } 5 \text { penumpang) sementara jika } \\
\text { penumpang dalam mobil banyak maka mobil akan menjadi mode } \\
\text { panjang (maksimal } 8 \text { penumpang). Panjang pendek mobil dapat } \\
\text { diatur dengan menekan tombol didalam mobil. }\end{array}$ \\
\hline 3 & Material Badan Mobil & $\begin{array}{l}\text { Menggunakan biofibre yang merupakan bahan yang dapat didaur } \\
\text { ulang serta ringan dan memiliki kekuatan yang sama dengan serat } \\
\text { karbon. Tujuannya agar membuat mobil lebih ringan sehingga dapat } \\
\text { membuat penggunaan energi lebih efisien. }\end{array}$ \\
\hline 4 & Mesin Mobil & $\begin{array}{l}\text { Mesin berkapasitas } 1200 \text { cc karena menurut Kementrian } \\
\text { Perindustrian Republik Indonesia bahwa Low Cost Green Car adalah } \\
\text { mobil dengan kapasitas mesin } 1.000 \mathrm{cc}-1200 \mathrm{cc} .1200 \mathrm{cc} \text { dipilih } \\
\text { agar tenaga yang dihasilkan SGC cukup besar untuk mengangkut } 8 \\
\text { penumpang. }\end{array}$ \\
\hline 5 & Baterai & Menggunakan aluminium air battery \\
\hline 6 & Keselamatan & $\begin{array}{l}\text { Full Airbag (dual, side dan curtain air bag), sensor keselamatan } \\
\text { (LKAS, LDW, AEB) }\end{array}$ \\
\hline 7 & Keamanan & $\begin{array}{l}\text { Fingerprint dan alarm (memberikan peringatan saat pintu mobil } \\
\text { dibuka secara paksa, peringatan ini terkoneksi dengan gadget } \\
\text { pemilik) }\end{array}$ \\
\hline 8 & Sistem Kemudi & $\begin{array}{l}\text { Sistem autonomous (mobil dapat mengemudi sendiri tanpa bantuan } \\
\text { manusia dengan perangkat kamera, sensor, radar, laser, GPS) dan } \\
\text { sistem manual }\end{array}$ \\
\hline 9 & Teknologi GPS & $\begin{array}{l}\text { GPS berteknologi tinggi yang dapat memberikan informasi secara } \\
\text { lengkap mengenai jalur alternatif, titik kemacetan, SPB terdekat, } \\
\text { bengkel terdekat. Sistem GPS juga terhubung dengan sistem } \\
\text { didalam gadget pemilik mobil sehingga kita dapat melacak titik } \\
\text { keberadaan mobil. }\end{array}$ \\
\hline
\end{tabular}

Lampiran 5. Concept of operations sistem SGC

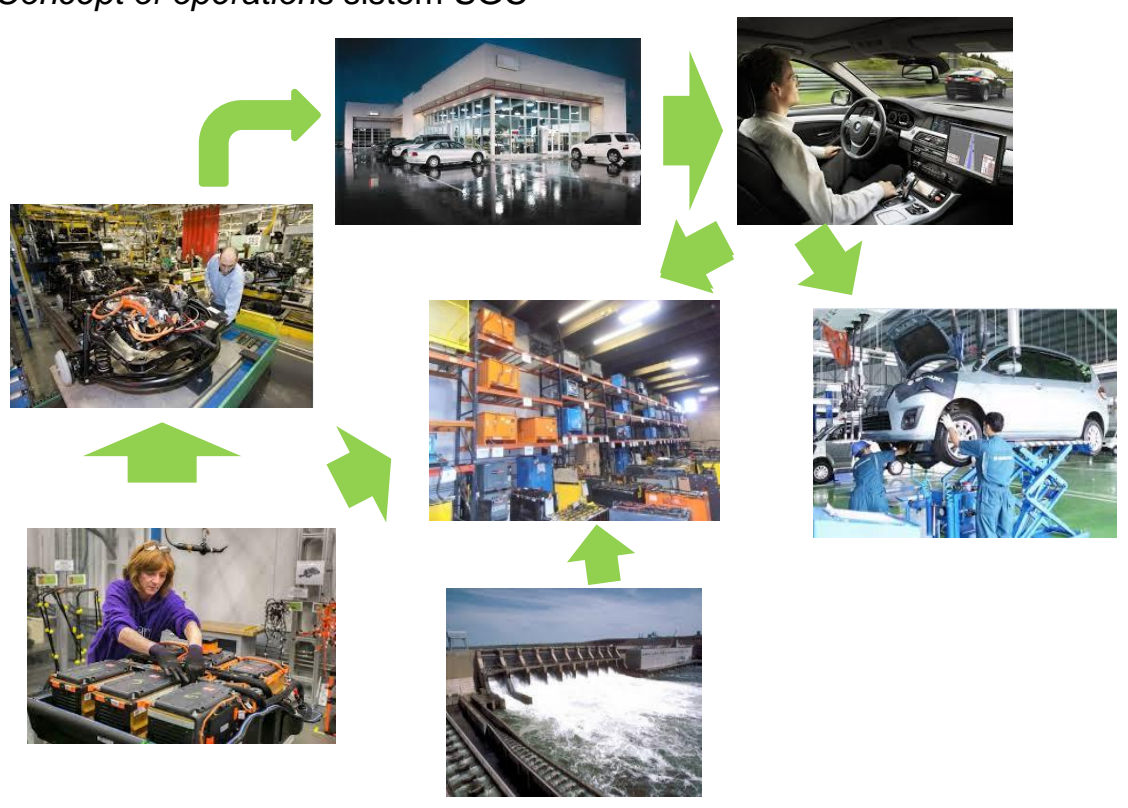


Halaman ini sengaja dikosongkan

This page is intentionally left blank 